\title{
Teološko-antropološka paradigma u rastućoj kulturi umjetnih inteligencija
}

Odilon-Gbènoukpo Singbo* odilonsing@gmail.com

https://orcid.org/0000-0002-2154-8935 https://doi.org/10.31192/np.18.1.4

UDK: 004.8:27-1

$179: 272-732.2$

Pregledni članak / Review

Primljeno: 17. studenog 2019.

Prihvaćeno: 28. siječnja 2020.

Sve više se na znanstveno-tehničkoj sceni govori o pojavi ili o dolasku nove vrste inteligencije, a to je tzv. umjetna inteligencija koja će navodno nadilaziti ljudsku inteligenciju. Stoga mnogi pokušavaju redefinirati pojam osobe da bi opravdali prisutnost »nove vrste ljudi« među nama. To nameće novu paradigmu u dijaloškom procesu. Riječ je o novoj pojavi koja će zasigurno utjecati na međuljudske odnose i o kojoj Drugi vatikanski koncil implicitno govori u Pastoralnoj konstituciji o Crkvi u suvremenom svijetu Gaudium et spes. Sveta Stolica, osobito papa Franjo, u više navrata je dotaknula ovu tematiku i posljedice koje donosi takav novi oblik dijaloga čovjeka i stroja s posebnim naglaskom na prednost čovjeka pred strojem. Čovjek bi time mogao izbjeći samouništenje te prevlast i nadmoć onoga što je sam stvorio svojim umom i svojim rukama.

Ključne riječi: emocija, etičko vrjednovanje, svijest, teološko promišljanje, umjetna inteligencija.

\footnotetext{
* Dr. sc. Odilon-Gbènoukpo Singbo, Hrvatsko katoličko sveučilište, Katedra za teologiju, Ilica 242, HR-10000 Zagreb.
} 


\section{Uvod}

U kratkom predgovoru svojem glasovitom djelu Rascjep $u$ svetome, Željko Mardešić daje kratak, jezgrovit, ali dubok i proročanski opis stanja stvari u suvremenom svijetu.

»Nema dvojbe da živimo u svijetu koji se iznenađujuće brzo mijenja i napušta tradicionalne obrasce mišljenja, djelovanja, ponašanja i snalaženja (...) Znanost također napreduje do neslućenih granica, a njezina primjena u tehnologiji olakšava ljudima život, povećava im blagostanje i udobnost svakidašnjice. To nam onda omogućuje društvenu sigurnost i ispunjenje želja i težnji, užitak i radost življenja, produžetak mladosti i slobodu neograničena izbora u sve bogatijoj ponudi predmeta i iskustva. Te su promjene dapače često brže od spremnosti i sposobnosti našeg praćenja i prilagođavanja, što izaziva nesnalaženje i otpore.«

Upravo potaknuti ovim riječima i suočeni s novim izazovima brzine, nespremnosti, radikalnih promjena, nesnalaženja u novom »tehnološkom društvu «, ${ }^{2}$ s izazovima koji su tek tinjali u vrijeme Mardešićeve proročke konstatacije, potrebno je na tragu njegovih misli raskrinkati, analizirati i vrjednovati nove promjene s kojima se danas susrećemo, a kojih nismo možda još dovoljno svjesni. Područje promišljanja u ovome članku obuhvaća umjetne inteligencije (UI) koje ćemo pokušati kratko predstaviti i kritički analizirati iz filozofsko-teološko-bioetičke perspektive.

\section{Preobrazba nužnosti u izbor}

Dana 26. ožujka 2019. nadbiskup Vincenzo Paglia, predsjednik Papinske akademije za život, u jednom je intervju započeo ovako: »Moramo cijeniti Božje darove, umjetna inteligencija zaslužuje našu punu pažnju. « ${ }^{3}$ Takva izjava bi mogla na prvi pogled zaintrigirati one koji gledaju tehnologiju isključivo negativnim očima. Ističući pozitivne strane novih tehnologija, nadbiskup smatra da je umjesto zamjene ljudi strojevima, važno razgovarati o potpori umjetne inteligencije ljudskom djelovanju, uz smanjenje troškova, počevši od potrošnje energije i optimalnog upravljanja resursima. Jasno je obznanio interes koji Sveta Stolica ima prema umjetnoj inteligenciji i odmah je najavio za 2020. godinu skupštinu koja će se baviti temom umjetnih inteligencija i antropološkim pitanjima vezanim uz njih. Nadbiskup Paglia dalje smatra da

\footnotetext{
1 Željko MARDEŠIĆ, Rascjep u svetome, Zagreb, Kršćanska sadašnjost, 2007, 5-6.

2 Jacques ELLUL, The Technological Society, 1964; ovdje se koristi izvorno, tj. francusko izdanje La Technique ou l'enjeu du siècle, iz 1954; ponovno izdano: Pariz, Economica, ${ }^{3} 2008$.

${ }^{3}$ Giacomo GALEAZZI, Paglia: Studiamo l'intelligenza artificiale. Ce lo ha chiesto il Papa (26.03.2019), https://www.lastampa.it/vatican-insider/it/2019/03/26/news/paglia-studiamo-lintelligenza-artificiale-ce-lo-ha-chiesto-il-papa-1.33690568?refresh_ce (17.11.2019).
} 
»u području znanstveno-tehnološkog istraživanja o robotima i na takozvanoj 'umjetnoj inteligenciji' ponekad se podrazumijeva - a ponekad je eksplicitna - predodžba o čovjeku, njegovu podrijetlu i odredištu, međutim ne uvijek prihvatljiva, odnosno nemoguće je u potpunosti obuhvatiti razliku koju nam pruža Sveto pismo između onoga što nam je u stvarnosti dano i što primamo kao besplatan dar Stvoritelja - Oca svih - i koliko je to zapravo plod ljudskog djelovanja koji taj dar preobražava «. ${ }^{4}$

Ovim promišljanjima, katolička teologija jasno ulazi u dijalog s izazovima suvremenih tehnologija ne odbacujući ih u potpunosti, niti ih prihvaćajući kao nesumnjiv Božji dar. Drugi vatikanski koncil je među raznim promjenama koje pogađaju tadašnje - i proročki gledajući sadašnje - društvo, govorio o novim oblicima života. Naime,

»Životne okolnosti modernog čovjeka s društvenog i kulturalnog stajališta duboko su se promijenile, tako da je opravdano govoriti o novom dobu ljudske povijesti. Odatle se otvaraju novi putovi usavršavanja i daljnjeg širenja kulture. Pripremio ih je golem razvoj znanosti o prirodi, o čovjeku i o društvu, porast tehničkih umijeća kao i napredak u izgradnji i ispravnom raspoređivanju sredstava kojima ljudi međusobno komuniciraju. $\aleph^{5}$

Nalazimo se, dakle, pred novom situacijom koja poziva na ulazak u radikalnost te situacije. Naime, ono što je bilo nužnost danas je postalo pitanje izbora. Danas imamo izbor: Želite li proteze ili zadržati svoje prirodne udove? Želite li pomoću čipova biti spojeni direktno s Wikipedijom ili nekom enciklopedijom ili pak napraviti naporan put do biblioteke? Pitanje znanja i znanosti je na taj način potpuno dematerijalizirano ili de-lokalizirano. Želite li poslati u rat dronove ili vojnike? Želite li pomoću tehnologije postati besmrtni ili ostati smrtnici? Želite li ostarjeti ili ostati vječno mladi? To su pitanja koja pokušavaju danas promijeniti nužnost u izbor. Jedno od područja koje nudi taj izbor je upravo razvoj umjetnih inteligencija. ${ }^{6}$

\section{Pokušaj definicije inteligencije}

Svaki pokušaj definicije inteligencije nosi opasnost redukcionizma upravo zbog širine, ali i nedokučivosti tog ljudskog svojstva. Dok će jedni istaknuti sposobnost logičnog razmišljanja i ponašanja, drugi će misliti na sposobnost razumijevanja, predviđanja, afektivnih spoznaja i samosvijesti. ${ }^{7}$ Neke definicije

\footnotetext{
${ }^{4}$ Isto.

${ }^{5}$ DRUGI VATIKANSKI KONCIL, Gaudium et spes. Pastoralna konstitucija o Crkvi u suvremenom svijetu (7.XI.1965), u: Dokumenti, Zagreb, Kršćanska sadašnjost, 2008, 54 (dalje GS).

${ }^{6}$ U nastavku se za umjetne inteligencije koristiti kraticu UI.

7 O robotima i mogućoj njihovoj svijesti vidi: Ivana GREGURIC, Kibernetička bića u doba znanstvenog humanizma. Prolegomena za kiborgoetiku, Zagreb, Hrvatsko filozofsko društvo - Pergamena - Znanstveni centar izvrsnosti za integrativnu bioetiku, 2018, 253-256.
} 
su dovoljno sveobuhvatne, iako opet ne govore sve. Prema Oxford Dictionary, inteligencija je sposobnost stjecanja i primjene znanja i vještine ili »sposobnost učenja, razumijevanja i razmišljanja na logičan način o stvarima ${ }^{8}{ }^{8}$ Zbog raznolikosti ciljeva, postoje razne vrste inteligencije. Stoga se s pravom može definirati inteligenciju kao »sposobnost vođenja do dobro složenih ciljeva«. ${ }^{9}$ Ljudska inteligencija u usporedbi s računalnom ima širi domet jer se ne ograničava samo na spajanju raznih zadanosti, već na stvaranje novih sadržaja. IBM-ov Deep Blue koji je pobijedio svjetskog šahovskog prvaka Garija Kasparova 1997. godine, pobjeđuje inteligencijom kojom je nesposoban čak doživjeti što je to pobjeda. Googleov DeepMind može postići razne ciljeve putem mnogo igara, ali ostaje ograničen u tome svijetu. Pobjeda u igri ne daje mu zadovoljstvo i smisao same pobjede. Zapravo, ne može znati kakav je taj osjećaj pobjede. Stroj ne postavlja pitanje o osjećaju koji proizlazi iz činjenice da smo nešto učinili. Jedino čovjek svojom inteligencijom može ostvariti takvo nešto. Tu se javlja tzv. »Moravčev paradoks« po kojemu je »lakše oponašati inteligenciju uspječnog igrača, nego inteligenciju djeteta od četiri godine $\ll^{10}$ Prava je igra inkarnacijska zbilja i zahtijeva prisutnost koja nije mučenje drugoga, već prilika za zajednički život. Igra uvodi čovjeka u društvenu dimenziju koja nadilazi puku pobjedu ili omalovažavanje drugoga. Stroj se ne prijavljuje za igru, ne zna za osjećaj gubitka i ustrajnosti u vježbanju itd. Treba, dakle, u definiciji inteligencije napraviti razliku između inteligencije i mimesisa inteligencije.

Usporedimo li inteligenciju strojeva s ljudskom, možemo reći da se područja primjene i razvoja ove prve umnažaju, ali su ujedno uska glede dubine i povratne veze jer upravo svijest nam pomaže da se osvrnemo na učinjeno i da postavljamo pitanja o kakvoći učinjenoga. To je čovjekovo trajno stanje ili sposobnost transcendencije, nadilaženja događaja i sebe. Inteligencija je nadalje zapravo umijeće upravljanja informacijama i donošenja novih ideja, novih koncepata iz tih informacija. Premda UI trenutno upravljaju informacijama, ne možemo reći da daju nove koncepte.

Nadalje, UI označavaju svekoliki informatički sustav koji u sebi ima sposobnost raznih radnji kojima nadilazi čovjekovu sposobnost na nekim područjima. Ovdje je uglavnom riječ o matematičkoj, informatičkoj, simulativnoj, algoritmičkoj inteligenciji koja se temelji na povezivanju zadanih programa. Stoga, govoriti o UI koja nadilaze čovjekovu inteligenciju ima stanovit redukcionistički pristup definiciji ne samo ljudske inteligencije, već ljudskosti općenito.

Ovaj pojam, koji se veže uz Johna McCarthya, službeno je dobio znanstveni uzlet godine 1956. prigodom ljetne škole koju su u Darmouthu organizirali

\footnotetext{
8 OXFORD LEARNER'S DICTIONARIES, Intelligence, https://www.oxfordlearnersdictionaries.com/definition/english/intelligence?q=intelligence (17.11.2019).

9 Max TEGMARK, La vie 3.0. Être humain à lère de l'intelligence artificielle, Malakoff, Dunod, 2018, 58.

${ }^{10}$ Dominique DE GRAMONT, Le christianisme est un transhumanisme, Pariz, Cerf, 2017, 64.
} 
Newell, Shaw i Simon. ${ }^{11}$ Pokušajem oblikovanja UI kao znanosti, može se reći da se dogodila »de-lokalizacija« inteligencije koja postaje prenosiva u strojeve. Na taj način korištenje pojma nije više vezano uz čovjeka, već se širi na područje informatike, odnosno računala. Informatički sustav prestaje biti isključivo sustav računanja i ulazi u sve sfere, kao što je npr. služenje ljudskim jezikom. Takva »deložacija« inteligencije neupitno nosi antropološko-egzistencijalne i epistemološke implikacije, jer mnogi, poput Hansa Moravca i Marvina Minskyja, kroz UI najavljuju nov oblik čovječnosti nakon ovoga koji poznamo, oblik života nakon života. ${ }^{12}$ Prema nekim autorima, poput Russela i Norviga, ${ }^{13}$ imamo nekoliko kategorizacija UI. Riječ je o sustavima koji misle kao čovjek, koji se ponašaju kao čovjek, koji misle racionalno, koji se ponašaju racionalno, koji ostavljaju dojam inteligencije. Dakle, sustavi čije nutarnje funkcioniranje pokušava biti u skladu s racionalnim bićem. Ti sustavi nastoje prepoznavati, povezivati i tumačiti većom brzinom nego što može čovjek kod nekih složenih vizualnih sadržaja. S UI je moguće obavljati neke poslove s većom preciznošću i točnošću nego što to može čovjek, odnosno poslove koji od čovjeka zahtijevaju više vremena i koncentracije.

Poznato je da je porijeklo UI vidljivo u Turingovom eksperimentu koji je on prikazao u članku Computing Machinery and Intelligence ${ }^{14}$ 1950. godine. Članak se bavi problematikom inteligencije stroja s pomoću eksperimenta koji je danas poznat kao Turingov. Cilj mu je dati dokaz koji bi bez dvojbe smatrao strojeve inteligentnima i svjesnima. Bilo kako bilo, glavni cilj UI je omogućiti strojevima radnje kojima će nadilaziti ljudsku inteligenciju.

\section{Neka područja primjene umjetnih inteligencija}

Već u mnogim staračkim domovima imamo robote koji pomažu starijim osobama da obave razne higijenske potrebe, da na vrijeme uzimaju lijekove itd. Da bi se pomoglo osobama s fizičkim poteškoćama, tzv. autonomna vozila nastoje im biti na raspolaganju. Osobama s demencijom ili s nekim drugim kognitivnim smetnjama pokušavaju vratiti ili nadomjestiti izgubljene sposobnosti. Na poseban način pojačavaju društvenost i pokretljivost osoba s invaliditetom. Roboti prate turiste, tumače im umjetnička djela, predstavljaju neke sadržaje. Govor o UI uvijek je povezan s raznim ciljanim reklamama na internetu za obradu raznih podataka, na digitalne strojeve i na tzv. humanoidne robote.

\footnotetext{
${ }^{11}$ Usp. Michel SIMON (ur.), La peau de l'âme. Intelligence artificielle et neurosciences. Approches pluridisciplinaires, Pariz, Cerf, 1994, 185.

${ }^{12}$ Isto, 239.

${ }^{13}$ Usp. Stuart RUSSELL, Peter NORVIG, Artificial Intelligence. A Modern Approach, London, Pearson, 2009.

${ }^{14}$ Alan TURING, Computing Machinery and Intelligence, Mind - a quarterly review of Psychology and Philosophy, 59 (1950) 236, 433-460.
} 
Algoritmi, kao kostur informatičkog sustava, pomažu digitalnim strojevima proizvoditi razne rezultate na temelju raspoloživih podataka i informacija. $\mathrm{Ti}$ su algoritmi »skriveni«, ali se aktiviraju kod raznih pretraživanja, kod medicinske dijagnostike na temelju statističkih podataka, kod odabira odredišta u automobilu pomoću GPS-a itd. Vlasništvo su izumitelja i dinamika njihova djelovanja često ostaje korisnicima nepoznata i nevažna. Zbog sposobnosti brzog računanja i povezivanja kompleksnih podataka, postaju sve moćniji u odrađivanju složenih radnji i u uspješnom ostvarenju tzv. deep learninga, tj. automatskog i dubinskog učenja. Takvo učenje omogućuje prepoznavanje slika, predmeta, lica, te upravljanje pametnim robotima. Europski Human Brain Project, povezujući neuroznanosti i UI, želi simulirati ljudski mozak do razumijevanja i svladavanja raznih mentalnih bolesti, ali i do dolaska superračunala ili neuromorfijskih računala koja bi kombinirala moć računala s fleksibilnošću ljudske inteligencije. ${ }^{15}$

Valja istaknuti da su UI dragocjene prilike za znanstveni i ekonomski razvoj. Spoj robotike i biomedicine donosi neizmjeran poticaj u ubrzavanju liječenja raznih bolesti, ali i u stvaranju boljih uvjeta za funkcioniranje. Dovoljno je spomenuti nama vrlo blizak primjer. Naime, 20. rujna 2019. objavljena je vijest ${ }^{16}$ o devetnaestogodišnjem Erminu Omeroviću iz Jajca kao prvom pacijentu na ovim prostorima kojemu je ugrađena proteza ruke koja se pokreće mislima. Zahvaljujući protezi sada može donekle upravljati tim udom kao nekada prije, što je omogućilo njegovu resocijalizaciju.

\section{Umjetne inteligencije: zastrašujući ili pomoćni sugovornici?}

Nemali je broj onih koji povezuju UI s mitom o Frankensteinu. Naime, godine 1818. Mary Shelley je objavila roman u kojem predstavlja doktora Victora Frankensteina koji je stvorio živo biće nakon što je spajao dijelove raznih leševa. ${ }^{17}$ Doktor Frankenstein je bio prestrašen zbog nastalog bića i pobjegao je, zaboravivši da je obdario inteligencijom to čudovište koje se željelo osvetiti svojem stvoritelju i čovječanstvu.

Na Praznik rada, 1. svibnja 2014., britanski fizičar Stephen Hawking oštro je upozorio na moguće nepovratne posljedice postmodernih UI. Prema njemu,

\footnotetext{
${ }^{15}$ Usp. https://www.humanbrainproject.eu/en/. Treba istaknuti da je projektu stavljena na raspolaganje 1 milijarda eura za deset godina istraživanja, tj. do 2024. godine.

${ }^{16}$ Elma DUVNJAK-ŠALAKA, Erminu Omeroviću iz Jajca u KCUS-u ugrađena proteza ruke koja se pokreće mislima (17.11.2019); https://faktor.ba/vijest/erminu-omerovicu-iz-jajca-u-kcusu-ugradena-proteza-ruke-koja-se-pokrece-mislima/52020 (17.11.2019).

${ }^{17}$ Usp. Mary SHELLEY, Frankenstein or the modern Prometheus, South Australia, The University of Adelaide Library, 1818.
} 
postoji velika vjerojatnost da UI zamijene ljude ${ }^{18}$ upravo zbog velike učinkovitosti robota. Drugi znanstvenici, poput Maxa Tegmarka, Franka Wilczeka i Stuarta Russela, dijele istu zabrinutost jer zbog sposobnosti učenja, koja kod strojeva postaje sve razvijenija posredstvom kolosalne količine informacija zvanih Big Data, velika je vjerojatnost da UI postane nepredvidiva i izmakne kontroli. Nadalje, Elon Musk, suosnivač kompanija Paypal, SpaceX, Tesla Motors, SolarCity, pokazuje nemir kada su u pitanju UI za koje smatra da nose rizike za čovjeka. U njima vidi najveću egzistencijalnu opasnost za čovječanstvo. ${ }^{19}$ Još jedno zvučno ime - Bill Gates - u siječnju 2015. pesimistički govori o opasnostima UI. ${ }^{20}$

Razmišljajući o umjetnim strojevima, papa Franjo je znakovito istaknuo da »suvremeni razvoj tehničkih mogućnosti proizvodi opasno očaranje: umjesto da donosi alate koji poboljšavaju brigu za ljudski život, postoji rizik davanja života logici tih uređaja koji odlučuju o njegovoj vrijednosti. Ovaj obrat predodređen je za stvaranje zlokobnih ishoda: stroj nije ograničen samo na upravljanje sobom, već nakraju upravlja čovjekom. Ljudski razum je tako sveden na racionalnost odvojenu od posljedica, što se ne može smatrati dostojnim čovjeka. ${ }^{21}$

Sveti Otac ide korak dalje i tvrdi da već postoji

»opasnost da čovjek bude tehniciziran, umjesto da je tehnika humanizirana: vrlo brzo se pripisuju tzv. 'pametnim strojevima' sposobnosti koje su ljudske vlastitosti. Trebamo bolje shvatiti što u ovom novom kontekstu znače inteligencija, svijest, emocionalnost, afektivna intencionalnost i autonomija moralnog djelovanja. Umjetni uređaji koji simuliraju ljudske sposobnosti su, ustvari, lišene ljudske kvalitete. ${ }^{22}$

Dodajemo li tome religioznu dimenziju UI, stvari postaju ili tragikomične ili zabrinjavajuće.

Naime, zastrašujuće je primijetiti da neki uzdižu UI na razinu božanstva. Tako je Anthony Levandowski, američki informatički inženjer, utemeljio 2015. godine Crkvu »Way of the Future« (WOTF) koja štuje UI. Premda na prvi

\footnotetext{
${ }^{18}$ Aatif SULLEYMAN, Stephen Hawking warns artificial intelligence 'may replace humans altogether' (02.11.2017), https://www.independent.co.uk/life-style/gadgets-and-tech/news/ stephen-hawking-artificial-intelligence-fears-ai-will-replace-humans-virus-life-a 8034341. html (17.11.2019).

${ }^{19}$ Usp. Miriam KRAMER, Elon MUSK, Artificial intelligence is humanity's »biggest existential threat « (27.10.2014), https://www.livescience.com/48481-elon-musk-artificial-intelligencethreat.html (09.07.2018).

${ }^{20}$ Eric MACK, Bill Gates Says You Should Worry About Artificial Intelligence, https://www. forbes.com/sites/ericmack/2015/01/28/bill-gates-also-worries-artificial-intelligence-is-a threat/\#6da70b6d651f (09.07.2019).

${ }^{21}$ Papa FRANJO, Discorso ai partecipanti all'assemblea plenaria della Pontificia Accademia per la vita (25.02.2019), http://w2.vatican.va/content/francesco/it/speeches/2019/february/documents/papa-francesco_20190225_plenaria-accademia-vita.html (17.11.2019).

${ }^{22}$ Isto.
} 
pogled ovo zvuči smiješno i irelevantno, treba istaknuti da je osnivač među začetnicima tzv. autonomnih automobila koji će uskoro biti naša svakodnevica. On smatra da »ono što će biti stvoreno zaista će biti bog «. ${ }^{23}$ WOTF je očiti znak divinizacije suvremenih tehnologija i dehumanizacije ljudske osobe.

Ray Kurzweil smatra da ćemo uskoro - zahvaljujući UI - moći »uploadati« našu svijest i prenijeti je na strojeve (mind uploading) ${ }^{24}$ i time će biti lakše postići besmrtnost: biološku, bioničku i virtualnu. ${ }^{25}$ Jedini zakon koji sad vrijedi $\mathrm{u}$ tehnološkoj evoluciji ostaje zakon eksponencijalnosti ${ }^{26} \mathrm{~s}$ brutalnom $\mathrm{i}$ »spasonosnom« promjenom. On proročki najavljuje za 2045.-2050. trenutak kada će čovječanstvo morati pristati na hibridizaciju da bi postiglo »metensomatozu«. Metensomatoza je prijelaz - meta, biološkog tijela - soma, u en - drugo tijelo. ${ }^{27}$ To je prijelaz ljudske svijesti u informatički sustav nakon moždane smrti. Kod ovog autora valja odmah primijetiti proces u koji smo već zakoračili, a to je proces humanizacije strojeva, s jedne strane, i mehanizacije čovjeka, s druge strane. Osim tehničkog pitanja o izvedivosti preuzimanja ljudske nematerijalne svijesti, bode u oči etičko pitanje o redukcionističkom pristupu čovjeku kao stroju bez dostojanstva i smisla.

Da UI nosi neizmjerne mogućnosti, ali i razloge za zabrinutost vidi se i kod Nicka Bostroma koji svojim bestsellerom znakovita naslova - Superintelligence: Paths, Dangers, Strategies, uviđa posljedice u našem tehnološkom društvu. Kao jedan od utemeljitelja transhumanističkog pokreta Humanity+ $(H+)$, tvrdi da će neizbježno nastati nov oblik čovječnosti - transhumanost kao humanost koja je viša, bolja, optimiziranija od one koju sada imamo, jer će nova imati moć i sposobnosti kojima može nadilaziti suvremene fizičke, psihičke, kognitivne i intelektualne granice. Jasno je da takav stav ne ide bez obezvrjeđivanja svetosti života. Prema Bostromu, najbolji način da se čovječanstvo bezbolno suoči s tim promjenama je odabir rađanja, tj. embrija putem oplodnje in vitro. To je, po njemu, pozitivna eugenika jer ima za cilj poboljšanje ljudske vrste. To je bezbolan i neškodljiv put za proširenje, pojačanje i optimiziranje inteligencije i time

\footnotetext{
${ }^{23}$ Raphaël ZBIDEN, Quand l'intelligence artificielle devient une divinité (28.02.2018), https:// www.cath.ch/newsf/lintelligence-artificielle-devient-divinite/ (17.11.2019).

${ }^{24}$ Usp. Ray KURZWEIL, The age of spiritual machines. When computers exceed human intelligence, London, Penguin books, 2000.

${ }^{25}$ Usp. Brent WATERS, Flesh Made Dana. The Posthuman Project in Light of the Incarnation, u: Calvin MERCER, Tracy J. TROTHEN, Religion and Transhumanism The Unknown Future of Human Enhancement, California, Paeger, 2015, 291-292.

${ }^{26}$ Riječ je o zakonu koji je godine 1965. izrekao Gordon Earle Moore, suosnivač firme Intel. Moore empirički smatra da se moć mikroprocesora (u računalima) udvostručuje svakih 18 mjeseci. Prema nekim autorima, ovaj zakon se već pokazuje kroz sljedeće najave: »Sredinom 2040-ih godina stvorena inteligencija na godišnjoj razini bit će otprilike milijardu puta moćnija od cjelokupne današnje ljudske inteligencije« (Ray KURZWEIL, Humanité 2.0. La bible du changement, Pariz, M21 Editions, 2007, 149).

${ }^{27}$ Jean-Gabriel GANASCIA, Le mythe de la singularité. Faut-il craindre l'intelligence artificielle?, Pariz, Seuil, 2017, 13.
} 
se može ostvariti ispunjenje čovjekovih čežnji. ${ }^{28}$ Teško je govoriti ili prihvatiti bilo kakvu pozitivnu eugeniku, jer sve što zadire u ontološku konzistentnost čovjeka ujedno uništava njegovu svrhovitost i jedinstvenost.

Ovaj prikaz u nastavku jezgrovito ističe etičko-egzistencijalna pitanja UI, ovisno o njihovoj razini razvoja. ${ }^{29}$

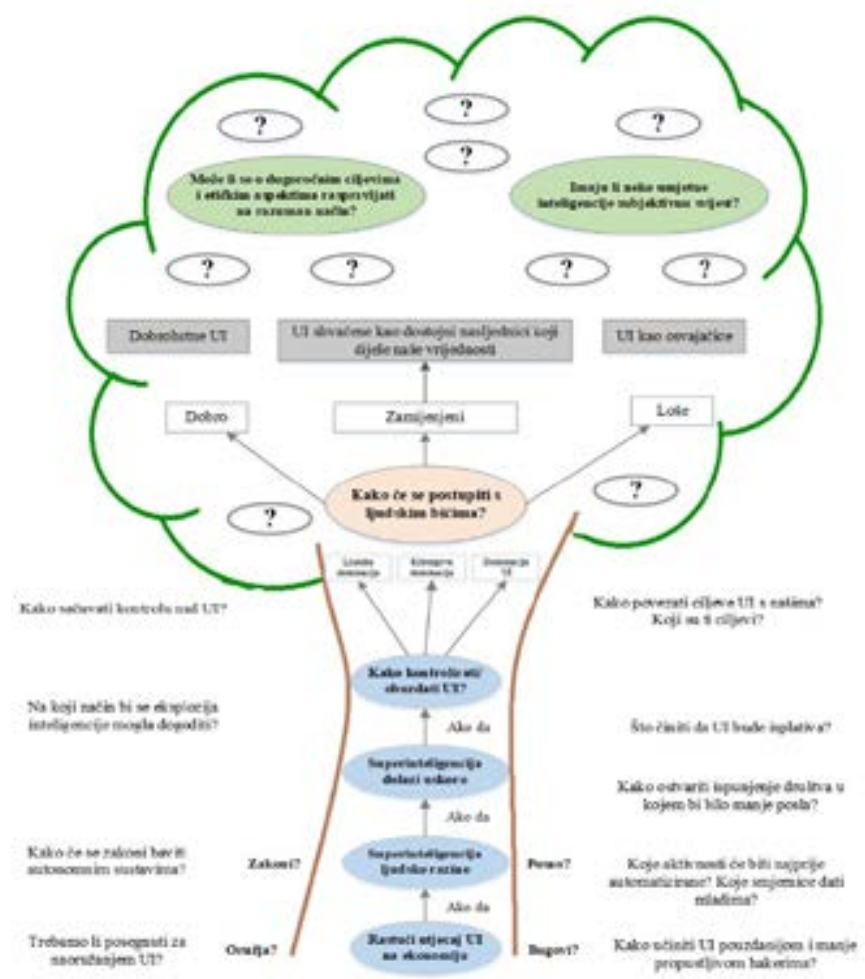

Filozofsko-antropološki prikaz mogućega sugovornika: Ja nisam robot!

Svima je poznat onaj proces s kojim se susrećemo i kojim nas se pita da ubacimo neke brojeve i slova koji su po sebi besmisleni, ali bez kojih ne možemo imati pristup internetskoj stranici koju želimo. Jednako su nam poznati razdražujući Googlovi tekstovi CAPTCHA (Completely Automated Public

\section{Submit}

Turing test to tell Computers and Humans Apart) kojima trebamo uvjeriti neku stranicu da smo ljudi. To je test razlikovanja računala od ljudi. No, pred raznim

\footnotetext{
${ }^{28}$ Usp. Nick BOSTROM, Superintelligence. Paths, Dangers, Strategies, Oxford, Oxford University Press, 2014, 14.

${ }^{29}$ Usp. Tegmark, La vie 3.0. Être humain..., 52.
} 
metodama kojima se može ugroziti te sustave Google je krajem 2014. stvorio novi sustav: »reCAPTCHA« koji traži da označimo u kućici »Ja nisam robot«, stvarajući u čovjeku znakovitu ironiju. Naime, u tom izrazu »Ja nisam robot« valja se upitati tko je taj »Ja « ako ne sam surfer koji potvrđuje da je sebe i »nekog drugoga « uvjerio da nije robot nego čovjek. Ustvari, on želi uvjeriti stroj i sebe u vlastitu ljudskost, a sam se ekran prikazuje kao neki »Ja«, želeći time čovjeka uvjeriti da ga poštuje i da treba samo kliknuti. Računalo je glavna instanca koja diktira pravila ponašanja. No, tko stoji iza ekrana i što mu znači taj moj/njegov »a nisam robot«? Zapravo robot mene robotizira. Nastaje asimetričan odnos jer sām robot kaže da nije robot i poziva mene da potvrđujem da nisam robot, a time je mene na poseban način robotizirao. Svojevoljno sam se dao u tu igru, jer je očito da bez te potvrdne geste ne mogu sebe ostvariti. Barem ne bih dobio ono što mislim da mi je tada potrebno. Sve podređujem tome, misleći da mi računalo pomaže afirmirati svoju ljudskost, a zapravo sam tom običnom gestom potvrdio da on upravlja mojim životom i da mu se klanjam: »Ako se dakle pokloniš preda mnom, sve je tvoje« $(\operatorname{Lk} 4,7)$. Događa se, dakle, svojevoljno robovanje (sobom), a to je najgori oblik ropstva, o čemu govori Boetije. ${ }^{30}$ Specifičnost je ovog ropstva u činjenici da nameće devijaciju zbilje u kojoj se konfrontiraju »tijelo« i svijesti čovjeka i stroja. Na taj je način promijenjen čovjekov identitet posredstvom stroja i posljedično se ugrožava njegova ontološka konzistentnost i pretvoren je u fluidno biće. Dok se pomoću tehnologije pretvara u »biće na putu auto-evolucije $\ll^{31}$ da bi nadilazio svoje biološke granice, dotle $u$ ruke UI predaje vodstvo i kontrolu.

Takav pristup zanemaruje da je jedna od bitnih osobina inteligencije otvorenost prema transcendenciji, ponizno divljenje pred neobjašnjivim otajstvom života ili upućivanje molbe $\mathrm{u}$ trenutcima kada se čovjek nalazi u »tamnoj noći«. Prava inteligencija (racionalna, umjetnička, emocionalna, mudrosna...) pretpostavlja okrenutost prema drugome, ne da bismo s njim riješili svoje trenutačne probleme, nego da bismo jednostavno bili s njim jer je drugi i drugačiji. Banalnije rečeno, UI ne znaju što je zapravo život s drugima, sa ženom, s mužem, sa svekrvom, sa snahom itd. Ukratko, takva inteligencija se ne »može sjećati jer ni ne može ništa zaboraviti, dakle, to je inteligencija bez povijesti, bez sposobnosti za patnju i bez morala«. ${ }^{32}$ Htjeti izjednačiti UI s ljudskom inteligencijom znak je nijekanja te transcendencije u čovjeku i, posljedično, stvaranje društva bez Gospodara života i povijesti.

\footnotetext{
${ }^{30}$ Usp. Etienne DE LA BOÉTIE, The politics of obedience. The Discourse of Voluntary Servitude, Montréal, Black Rose Books, 1975.

${ }^{31}$ Pascal PICQ, Michel SERRES, Jean-Didier VINCENT, Qu'est-ce que l'humain?, Pariz, Le Pommier, 2010, 88.

${ }^{32}$ Johann Baptist METZ, Politička teologija, Zagreb, Kršćanska sadašnjost, 2004, 212.
} 


\section{Nove antropološko-etičke perspektive}

\subsection{Osobnost novih inteligencija}

Promišljanje o novoj kulturi UI nameće i pitanje etičkog statusa tih inteligencija u njihovu odnosu prema čovjeku, odnosno čovjekova odnosa prema njima. Zbog mogućeg postignuća izgradnje UI u kojem bi stroj imao samosvijest, neki smatraju da je vrijeme za redefiniranje pojma osobe koji treba barem dijelom obuhvatiti strojeve. Europski parlament u jednom dokumentu potiče na istraživanja koja bi dala nekim robotima status »elektroničke osobe«. ${ }^{33}$ Riječ je o pravnoj osobnosti robota, odnosno o stvaranju pravnih okvira da bi roboti, »barem oni autonomni i sofisticirani bili smatrani elektroničnim odgovornim osobama « ${ }^{34}$ i koji bi kao takvi bili obvezni popraviti štetu koju bi nanijeli nekome. Traži se, dakle, da se dadne »elektronička osobnost« svakom robotu koji donosi tzv. autonomne odluke. Time taj pojam prestaje biti svojstvo čovjeka, ali i Boga u kršćanskoj tradiciji. No, držimo: i kad bi strojevi postigli neki stupanj samosvijesti bila bi to repetitivna samosvijest. Konstitutivna, kreativna i ontološka samosvijest isključiva je vlastitost ljudske vrste. Etički gledano robot kao mogući sugovornik

»uvijek ostaje pod odgovornošću njegovih izumitelja i korisnika. Ne posjeduje slobodu volje i njega ne zanima istina radi same istine, nego ga zanima primjena njegova programa. I jako je zabrinjavajuće vidjeti razvoj seksualnih robota koji pretendiraju zamijeniti ljubavnu intimnost s drugom ljudskom osobom. ॥ $^{35}$

Očigledno je da takav pravno-etičko-identitetski pristup novim inteligencijama svjedoči o »ontološkoj podložnosti« i »prometejskom poniženju« ${ }^{36}$ čovjeka jer relativizira sam pojam osobe koji je duboko povezan s dostojanstvom čovjeka. Prikladniji nam se čini pojam $» k o g n i t i v n i$ robot ${ }^{37}$ koji više odgovara namjeri stvaranja tih inteligencija. Iako nas takav naziv ne oslobađa pitanja do koje razine se te inteligencije mogu približiti ljudskoj inteligenciji, valja ista-

\footnotetext{
${ }^{33}$ European Parliament resolution of 16 February 2017 with recommendations to the Commission on Civil Law Rules on Robotics; http://www.europarl.europa.eu/doceo/document/TA8-2017-0051_EN.html (08.08.2019). Ne smijemo zaboraviti također na robot japanske firme Hanson Robotics Sofiju kojoj je Saudijska Arabija 25. listopada 2017. dala državljanstvo.

${ }^{34}$ Isto.

${ }^{35}$ CONSEIL PERMANENT DE LA CONFÉRENCE DES ÉVÊQUES DE FRANCE, Qu'est-ce que l'homme pour que tu penses à lui?, Pariz, Bayard - Cerf - Mame, 2019, 46-47; usp. Josip MUŽIĆ, Rat protiv čovjeka. Ideologije i prakse raščovječenja, Zagreb, Glas Koncila, 2015, 405; Laurent ALEXANDRE, Jean-Michel BESNIER, Les robots font-ils l'amour? Le transhumanisme en 12 questions, Pariz, Dunod, 2016, 55-60.

${ }^{36}$ Jacques TESTART, Agnès ROUSSEAUX, Au péril de l'humain. Les promesses suicidaires des transhumanistes, Pariz, Seuil, 2018, 149-150.

${ }^{37}$ Pojam rabi Francuska biskupska konferencija u svojem dokumentu »Intelligence Artificielle«; https://eglise.catholique.fr/wp-content/uploads/sites/2/2018/03/06.-Intelligence-artificielle. pdf (17.11.2019).
} 
knuti da ima svoju vrijednost po tome što jasno razgraničuje i imenuje zbilje. Naime, roboti su zamišljeni da imitiraju funkcioniranje ljudskog mozga. No, $\mathrm{s}$ obzirom na to da imitacija ne znači apsolutno reproduciranje svih svojstava imitiranoga, teško je primijeniti sveobuhvatan opis onog što se imitira. A robot sa svojim korijenom »rob«, ostaje na taj način imitator i sluga koji je upravo $u$ službi onog kojeg imitira.

\subsection{Emocije i ranjivost kao bogatstva}

Nema sumnje da su računala u računanju moćnija od čovjeka. No, možemo li svesti inteligenciju samo na sposobnost računanja? Mnogi pobornici UI smatraju da misliti znači računati. Računati znači donekle misliti. Međutim, misao nije prije svega stvar računa. U trenutku kada neuroznanosti govore o odnosu između razuma i emocija, postoji oblik računalne i racionalne inteligencije $u$ ljudskom mozgu koji UI nastoje oponašati, a možda i nadilaziti. Ali imamo i ulogu emocija koje UI nastoje simulirati, ali bi ih teško nadilazile.

U dinamičnom odnosu stroja i čovjeka uvijek postoji nepremostiva granica između simuliranja emocije i njenog doživljaja. Naime, emocija ima komunikacijsku dimenziju koja navodi čovjeka koji je doživljava i proživljava da neke vrijednosti pridoda stvarima i događajima što mu pomaže u svakodnevnom odlučivanju. Moć UI jasno pokazuje da tehnološki sustav rađa vlastite načine promišljanja o čovjeku. Prema tome, ako misliti znači samo računati, evidentno je da stroj može postati novi čovjekov takmac i da ga može jednog dana nadići i staviti u stanje podređenosti i zarobljenosti. Tehnološka paradigmatska promišljanja poistovjećuju cjelinu s dijelom. Naime, ideja prenošenja uma u stroj temelji se na neodrživom neuroredukcionizmu koji pogrešno postavlja mozak za jedini supstrat uma, zaboravljajući da su životni procesi neraskidivo povezani kroz živo tijelo kao cjelinu. U jedinstvu osobe oba su aspekta isprepletena: tijelo je živo i stoga također umno; um je živ i zato je ujedno istinski utjelovljena zbilja. ${ }^{38}$

Vratimo se na emocije. Gotovo svaka izražava bogatstvo ranjivog čovjeka. »Znam što je strah, ali ne znam kada ga trebam doživjeti«, reče robot svome izumitelju, ${ }^{39}$ dok je kod ljudi obrnuto. Ne znamo do kraja definirati što je strah, ali znamo kada ga doživljavamo. I to govori o razini ranjivosti u nama. UI nemaju takvu ranjivost koja humanizira ljudski život. Također je nemoguće usporediti ljudsku svijest - koja je po sebi egzistencijalna, psihološka i ćudoredna ${ }^{40}$ - s mogućom i navodnom svijesti stroja. Takva usporedba je moguća jedino ako prihvaćamo redukcionističku definiciju inteligencije. A to stvara ogromnu zbunjenost jer je čovjek po svojoj stvorenosti na sliku Božju (Post 1, 27) obdaren

\footnotetext{
${ }^{38}$ Usp. Thomas FUCHS, Ecology of the Brain. The phenomenology and biology of the embodied mind, Oxford, Oxford University Press, 2018, 138 i 228.

${ }^{39}$ Usp. Isaac ASIMOV, Le cycle des robots, Tome 1: Les robots, Pariz, J’AI LU, 2012.

${ }^{40}$ Usp. GS 16.
} 
slobodom, istinom i mudrošću, što ga stavlja u drugačiji položaj glede promišljanja i djelovanja. To je položaj koji se neprestano usavršuje - ne pomoću tehnoloških implantata, već mudrošću »koja blago privlači čovječji duh da traga za istinom i dobrom i da ih ljubi; njima prožet, čovjek je po vidljivome vođen prema nevidljivome« (GS 15). Naša svijest i savjest nalaze se u stvorenom i od Boga oblikovanom tijelu i prenose se kroz tisućljeća evolucije svim ljudskim bićima, ne kao stanje prokletstva i promašaja, već kao otajstvena zbiljnost puna raznih sposobnosti i svojstava - kao što je besmrtna duša, razum, kreativnost, raspoloženje za transcendentno itd. - a sve to nadilazi najuzvišenije i najsofisticiranije tehničke kombinatorike.

Nadalje, stvaranja superinteligencije, kao krune prožimanja čovjeka i stroja, govori o unutarnjoj ljudskoj tjeskobi i umoru od onog što znači biti čovjek. Iz perspektive UI možemo reći da težnja za tim prožimanjem vodi do kognitivno-sintetičkog stanja: homo-machina sapiens. ${ }^{41}$ Takav spoj želi nadilaziti sve što je manjkavo u čovjeku. Time niječe činjenicu da je događaj Isusa Krista ostvario svoju puninu upravo u trenutku kada je On prihvatio našu ljudsku ograničenost i konačnost. Nalazimo se u epohi koja promiče kult performansa, vječne mladosti, odnosno "produžetka mladosti « ${ }^{42}$ i koja odbacuje činjenicu da nijekanje naših granica zapravo znači dodatno ranjavanje sebe i čežnju za životom koji nije ljudski.

\section{Zaključak}

Nema dvojbe da stvarnost UI postaje gorući izazov filozofsko-teološkom promišljanju. S obzirom na njihovu ulogu buđenja svijesti, možemo reći da su teologiji i filozofiji UI postale novi locus theologicus. Naime, UI zadiru u samu ontologiju upravo zbog programske i paradigmatske namjere da promijene identitetsku narav čovjeka sve do njezina nadilaženja. Ovaj je članak svojevrstan uvod u daljnje istraživanje i teološko-etičko vrjednovanje UI. Cilj takvog vrjednovanja nipošto nije tehnofilske niti tehnofobske naravi, već ozbiljno uzimanje u obzir činjeničnog stanja, novih mogućnosti, ali i mogućih prijetnji na području rada i same ljudske naravi. Zbog stvorenosti na sliku Božju, čovjek ostaje jedino biće koje zaslužuje identitetski opis sadržan u pojmu osobe. A to govori o njegovom inherentnom dostojanstvu koje ne potvrđuju znanosti, tehnologije niti išta drugo što je čovjekov izum. To dostojanstvo valja spasiti unatoč primamljivim obećanjima raznih znanstveno-tehničkih dostignuća koja mogu u mnogočemu poboljšati životne uvjete na zemlji, ali nikako zamijeniti čovjeka.

\footnotetext{
${ }^{41}$ Usp. Paolo BENANTI, Le macchine sapienti. Intelligenze artificiali e decisioni umane, Bologna, Marietti, 2019, 113-114.

${ }^{42}$ Mardešić, Rascjep u svetome..., 5.
} 


\section{Odilon-Gbènoukpo Singbo* \\ Theological and Anthropological Paradigm in Growing Culture of Artificial Intelligences \\ Summary}

On scientific-technological scene more and more are talked about presence or arrival of a new type of intelligence, and that is so-called artificial intelligence that will allegedly overcome the human intelligence. Therefore, many are in pursuit for redefining the term of person to justify the presence of a »new kind of human" among us. Such kind of phenomenon imposes a new paradigm in dialogical process. It is about a new phenomenon that will surely impact on interpersonal relationships, and which the Second Vatican Council is implicitly talking in Pastoral constitution on the Church in the modern world Gaudium et spes. The Holy See itself, especially Pope Francis, in several cases touched this theme and consequences that carries such new shape of dialogue between human and the machine with emphasis on advantage of human over the machine. In this way, we will be able to avoid self-destruction, predominance and superiority of what we have created with our own hands.

Key words: artificial intelligences, awareness, emotion, ethical evaluation, theological deliberation.

(na engl. prev. Odilon-Gbènoukpo Singbo)

\footnotetext{
* Odilon-Gbènoukpo Singbo, PhD, Catholic University of Croatia, Chair of Theology; Address: Ilica 242, HR-10000 Zagreb, Croatia; E-mail: odilonsing@gmail.com.
} 